\title{
Synthesis and Biological Evaluation of New Chromenes and Chromeno[2,3-d] pyrimidines
}

\author{
Fatima Belhadja, ${ }^{\mathrm{a}}$ (i) Zahira Kibou, ${ }^{\mathrm{a}, \mathrm{d}}$, Mohammed Benabdallaha, Mohammed Aissaouie, \\ Mohammed Nadjib Rahmoune, Didier Villemin ${ }^{c}$ and Noureddine Choukchou-Braham ${ }^{a}$ \\ aLaboratoire de Catalyse et Synthèse en Chimie Organique, Faculté des Sciences, Université de Tlemcen, BP 119 Tlemcen, Algeria \\ ${ }^{b}$ Université d'Oran 1, Faculté de Médecine, B.P.1510 ELMENAOUAR, 31000 Oran, Algeria \\ 'LCMT, ENSICAEN, UMR CNRS 6507, 6 Bd du Maréchal Juin, 14050 Caen, France \\ ¿Université d'Ain Témouchent, Faculté des Sciences et de la technologie, BP 284, 46000 Ain Témouchent, Algeria \\ ¿Laboratoire Antibiotiques Antifongiques : Physico-Chimie, Synthèse et Activité Biologique, Faculté de SNV-STU, Université de Tlemcen, 13000 Tlemcen, Algeria
}

Received 27 September 2020, revised 28 January 2021, accepted 01 February 2021

\begin{abstract}
A simple and efficient approach has been developed to synthesise novel and functionalised $5 H$-chromeno[2,3- $d]$ pyrimidines derivatives $(4 a-h)$. This approach entails treating 2-amino-3-cyano-4H-chromenes (3a-h) with formamidine acetate under microwave irradiations and solvent-free conditions. All structures of new compounds obtained in this study were characterised by IR, MS, 1H and 13C NMR analysis. Additionally, the synthesised compounds were investigated for their antibacterial and antioxidant potential. Compounds $3 b, 3 c, 3 e, 4 c$ and $4 e$ showed significant activities.
\end{abstract}

KEYWORDS

$5 H$-chromeno[2,3-d] pyrimidine; $4 H$-chromene; solvent-free conditions; antioxidant activity; antibacterial activity

\section{Introduction}

The fusion of chromene fragments with different heterocycle scaffolds gives rise to a new class of hybrid heterocycles: $5 H$-chromeno[2,3-d] pyrimidine. These motifs are wellestablished in the literature as important biologically effective heterocyclic compounds. ${ }^{1,2,3,4,5}$ These compounds are the subject of many research studies due to their large potential for pharmacological activities. These activities include antitumoral, ${ }^{6}$ antibacterial, ${ }^{7}$ anti-fungicidal, analgesic, ${ }^{8}$ anti-allergic, ${ }^{9}$ cardiotonic, hepatoprotective, ${ }^{10}$ antihypertensive, ${ }^{11}$ activity.

In continuation of our efforts toward constructing heterocyclic compounds, ${ }^{12,13,14,15}$ the present work reports an efficient process for the synthesis of $5 \mathrm{H}$-chromeno[2,3-d] pyrimidines derivatives. The key step in our strategy is based on the condensation of 2-amino-3-cyano- $4 \mathrm{H}$-chromenes with formamidine acetate. The structures of these new compounds were characterised by spectroscopic analysis and evaluated for their antioxidant and antibacterial activities.

\section{Results and Discussion}

The synthesis of the new $5 \mathrm{H}$-chromeno[2,3- $d$ ] pyrimidine derivatives was obtained through a two-step method, as shown in Scheme 1. The first step was based on the synthesis of 2-amino-3-cyano-4H-chromenes (3a-h). This step was followed by cyclisation and condensation to the $5 H$-chromeno[2,3-d] pyrimidines in the second step.

\subsection{Synthesis of 2 -amino-3-cyano- $4 \mathrm{H}$-chromenes ( $3 \mathrm{a}-\mathrm{h}$ )}

The general synthesis of 2-amino-3-cyano- $4 \mathrm{H}$-chromenes includes the reaction of arylidene malononitriles and $\beta$-dicarbonyl compounds in the presence of piperidine, ${ }^{16}$ triethylamine, ${ }^{17} \mathrm{Ca}(\mathrm{OH})_{2}{ }^{18}$ or TFE. ${ }^{19}$ Most of these methods involve the use of volatile solvents, expensive reagents and require longer reaction times. We found that these reactions can be carried out without a base and a catalyst. Consequently,
2-amino-3-cyano-4H-chromenes (3a-h) were obtained by condensation of stoichiometric amounts of substituted resorcinol, malononitrile and aromatic aldehydes under microwave for $5 \mathrm{~min}$ (Scheme 2).

The results obtained for the preparation of compound $\mathbf{3 a}-\mathbf{h}$, with excellent yield (82-97\%), are reported in Table 1. The use of microwave allowed us to reduce the reaction time from $24 \mathrm{~h}$ to $5 \mathrm{~min}$. NMR spectra of $\mathbf{3 a}-\mathbf{h}$ showed characteristic signals for $4 H$-chromenes: singlets at $\delta_{\mathrm{H}} 4.49-4.67 \mathrm{ppm}$ in the ${ }^{1} \mathrm{HNMR}$ and at $\delta_{\mathrm{C}} 54.87-56.97 \mathrm{ppm}$ in the ${ }^{13} \mathrm{CNMR}$. The IR spectra showed a $\mathrm{CN}$ stretch at $v 2197-2223 \mathrm{~cm}^{-1}, \mathrm{NH}_{2}$ stretch at $v 3420-3362 \mathrm{~cm}^{-1}$, CO stretch at $v 1670-1675 \mathrm{~cm}^{-1}$ and $\mathrm{OH}$ at $v 3420-3446 \mathrm{~cm}^{-1}$. For all the compounds, the mass spectra gave additional evidence for the proposed structures.

The proposed mechanism for the formation of 2-amino-3cyano- $4 H$-chromenes (3a-h) is described in Scheme 3. First, we have the formation of alkene I by the Knoevenagel condensation of aromatic aldehyde and malononitrile. A 1,4-Michael addition of II with alkene I form intermediate III. This intermediate is converted to intermediate IV by intramolecular cyclisation.

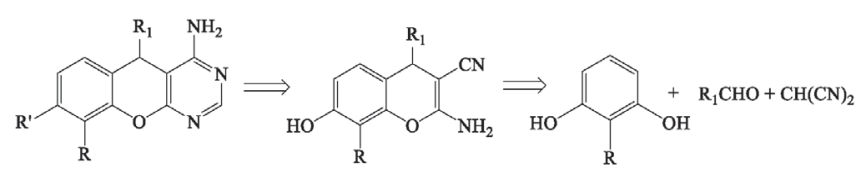

Scheme 1 Retrosynthetic scheme of the preparation of the $5 H$-chromeno[2,3- $d$ ] pyrimidines derivatives

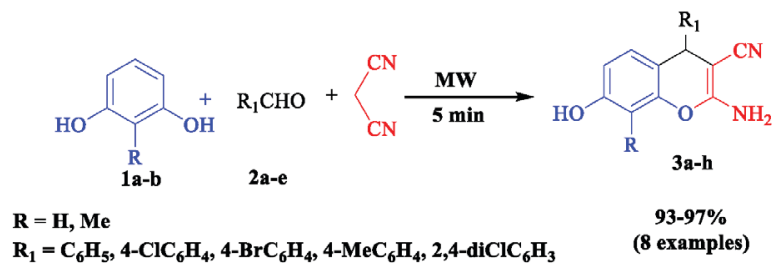

Scheme 2 Synthesis of 2-amino-3-cyano-4H-chromenes (3a-h) 
Table 1 Results of synthesis of 2-amino-3-cyano-4H-chromenes (3a-h)

\begin{tabular}{|c|c|c|c|c|c|}
\hline \multirow{2}{*}{$\mathrm{R}$} & \multirow{2}{*}{ R1 } & \multirow{2}{*}{ Products } & \multirow{2}{*}{$\begin{array}{c}\text { Yield } \\
(\%)\end{array}$} & \multicolumn{2}{|c|}{$\mathrm{Mp}{ }^{\circ} \mathrm{C}$} \\
\hline & & & & Found & Reported \\
\hline \multirow{5}{*}{$\mathrm{H}$} & $\mathrm{C}_{6} \mathrm{H}_{5}$ & & 95 & 235 & $234-237^{20}$ \\
\hline & $4-\mathrm{ClC}_{6} \mathrm{H}_{4}$ & & 97 & 162 & $161-162^{21}$ \\
\hline & $4-\mathrm{BrC}_{6} \mathrm{H}_{4}$ & & 97 & 224 & $224-226^{21}$ \\
\hline & $4-\mathrm{MeC}_{6} \mathrm{H}_{4}$ & & 96 & 184 & $183-186^{20}$ \\
\hline & 2,4- $\mathrm{diClC}_{6} \mathrm{H}_{3}$ & & 95 & 256 & $256-258^{20}$ \\
\hline \multirow{3}{*}{$\mathrm{Me}$} & $\mathrm{C}_{6} \mathrm{H}_{5}$ & & 93 & 235 & - \\
\hline & $4-\mathrm{ClC}_{6} \mathrm{H}_{4}$ & & 95 & 240 & - \\
\hline & $4-\mathrm{BrC}_{6} \mathrm{H}_{4}$ & & 94 & 243 & - \\
\hline & & & & & \\
\hline
\end{tabular}

A rearrangement of intermediate IV produces the expected 2-amino- $4 H$-chromenes.

\subsection{Synthesis of 4 -amino-5H-chromeno[2,3-d] pyrimidines (4a-h)}

Different synthetic methods of 4-amino-5H-chromeno[2,3-d] pyrimidines have been reviewed. ${ }^{22,23,24,25}$ In this context and in order to obtain new bioactive heterocyclic compounds, the formamidine acetate was added to the 2-amino-3-cyano- $4 \mathrm{H}$ chromenes (3a-h) (Scheme 4) via microwave heating. The originality of our synthetic strategy is based on the use of formamidine acetate as a cyclisation agent. This reagent is a very useful intermediate in synthesising various heterocycles, especially pyrimidine synthesis, through its reaction with unsaturated 2-aminonitriles.

The results obtained for the synthesis of compound $\mathbf{4 a - h}$ with good yield (85-95\%) are summarised in Table 2.

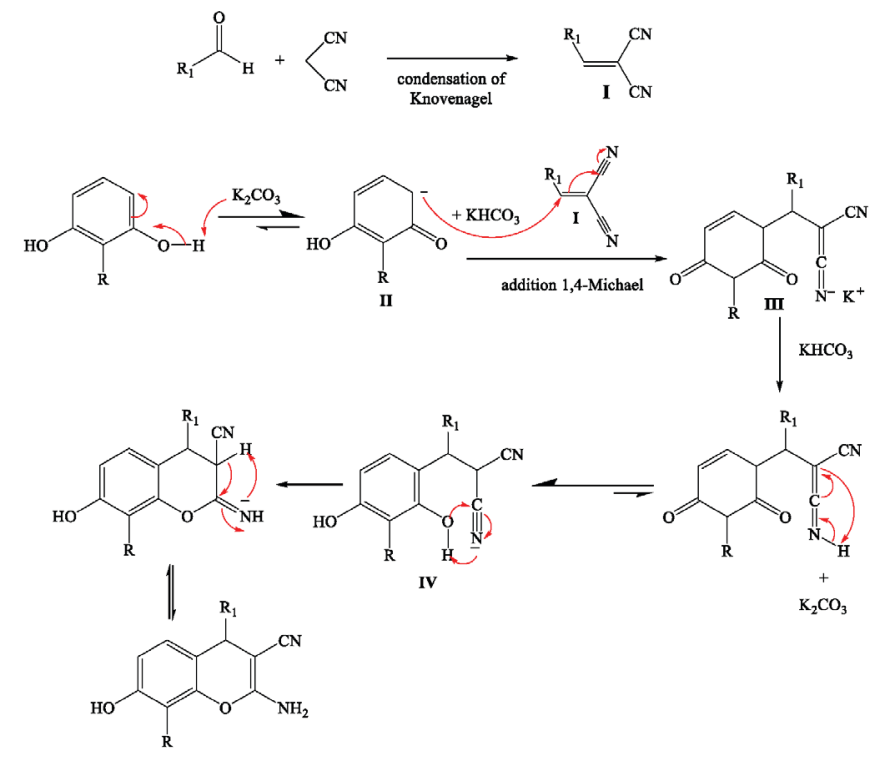

Scheme 3 Proposed mechanism for the formation of 2-amino-3-cyano$4 H$-chromenes derivatives (3a-h)

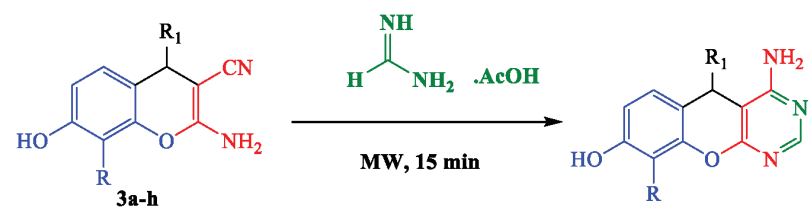

$\mathbf{R}=\mathbf{H}, \mathbf{M e}$

$\mathbf{R}_{1}=\mathrm{C}_{6} \mathrm{H}_{5}, 4-\mathrm{ClC}_{6} \mathrm{H}_{4}, 4-\mathrm{BrC}_{6} \mathrm{H}_{4}, 4-\mathrm{MeC}_{6} \mathrm{H}_{4}, 2,4-\mathrm{diClC}_{6} \mathrm{H}_{3}$

85-95\% (8 examples)

Scheme 4 Synthesis of 4 -amino- $5 H$-chromeno[2,3-d] pyrimidines $(4 a-h)$

The treatment of 2-amino-3-cyano- $4 H$-chromenes (3a-h) with formamidine acetate, without solvent and under microwave irradiation for $15 \mathrm{~min}$, gave the corresponding 4-amino- $5 \mathrm{H}$ chromeno[2,3- $d$ ] pyrimidines $(\mathbf{4} \mathbf{a}-\mathbf{h})$ with good yields. The IR spectra showed the absence of $\mathrm{CN}$ and the appearance of $(\mathrm{C}=\mathrm{N})$ at $v 1645-1649 \mathrm{~cm}^{-1}, \mathrm{NH}_{2}$ stretch at $v 3465-3402,3356-$ $3324 \mathrm{~cm}^{-1}$ and CO stretch at $v 1671-1675 \mathrm{~cm}^{-1}$. The structures of the compounds $4 \mathbf{a}-\mathbf{h}$ were confirmed based on ${ }^{1} \mathrm{H}$ NMR, ${ }^{13} \mathrm{C}$ NMR and MS data.

The mechanism proposed for forming 4-amino-5 $\mathrm{H}$ chromeno[2,3- $d$ ] pyrimidines $(\mathbf{4} \mathbf{a}-\mathbf{h})$ was described in Scheme 5. The reaction begins with the formation of the intermediate $\mathbf{I}$. The latter undergoes a nucleophilic addition of the $\mathrm{NH}_{2}$ group

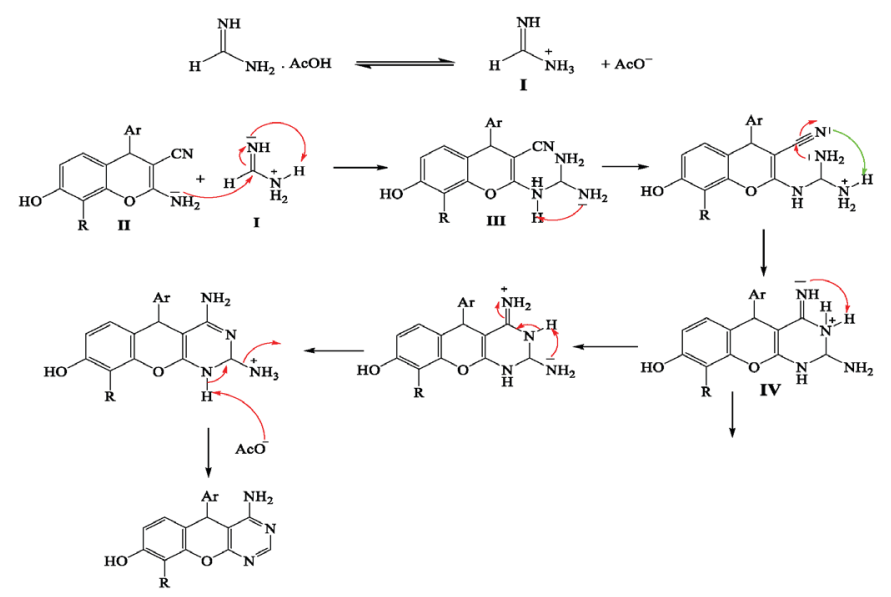

Scheme 5 Proposed mechanism for the formation of 4-amino-5Hchromeno[2,3-d] pyrimidines derivatives $(\mathbf{4} \mathbf{a}-\mathbf{h})$ 
Table 2 Results of synthesis of 4-amino-5H-chromeno[2,3-d] pyrimidines (4a-h)

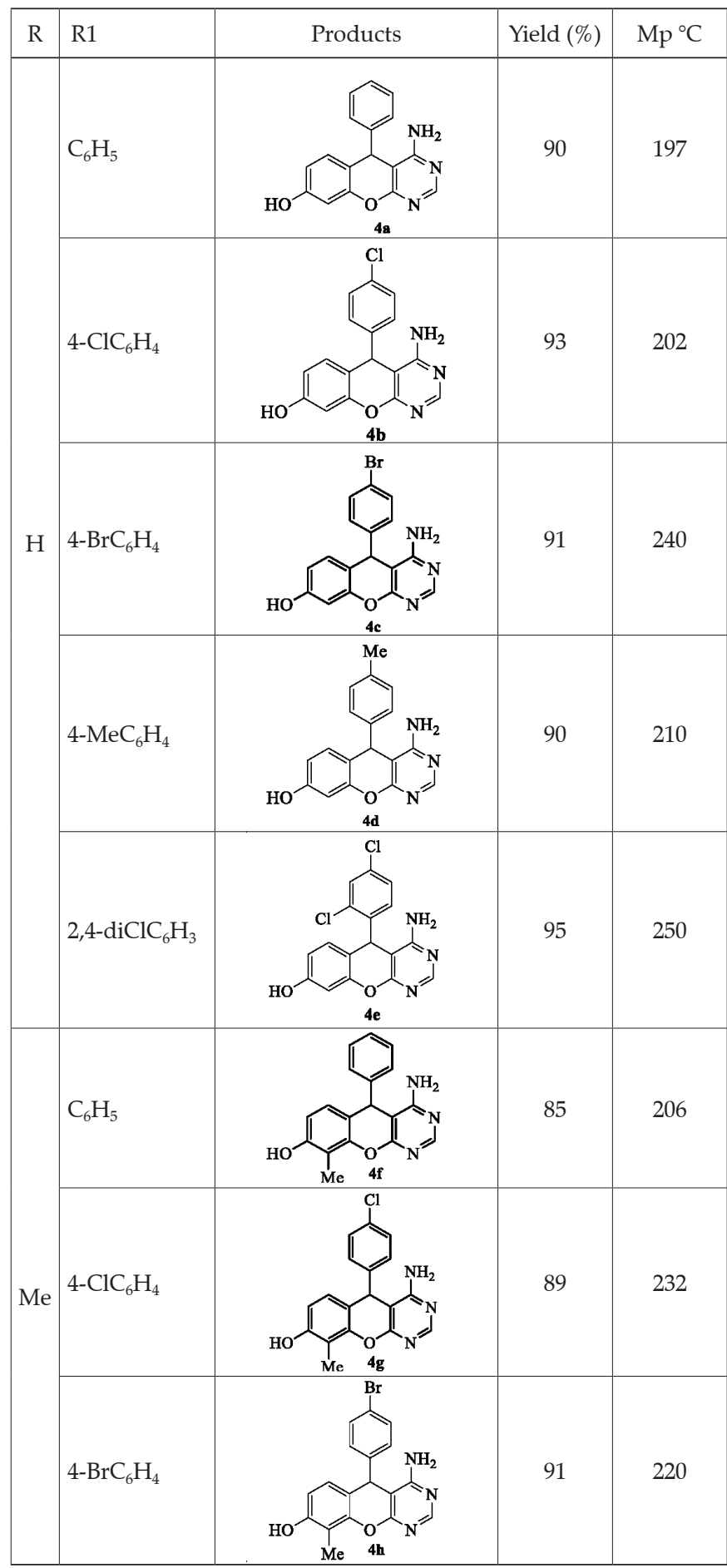

of 2-amino-3-cyano-4H-chromene (II) to form intermediate III. The formation of III is followed by intramolecular cyclisation of the $\mathrm{NH}_{2}$ group with the $\mathrm{CN}$ group to give intermediate IV. After rearrangement and a step of aromatisation, 4-amino-5Hchromeno[2,3-d] pyrimidine was obtained.

\section{Biological Evaluation}

\subsection{Determination of antibacterial and antioxidant activity -} The disc diffusion method

A panel of bacteria, namely Escherichia coli ATCC (American Type Culture Collection) 25922, Salmonella typhimurium ATCC 13311, Klesialla pneumonia ATCC 700603, Citrobacter freundi ATCC 8090, Pseudomonas aeruginosa ATCC 27853, Staphylococcus aureus ATCC 25929, Enterococcus faecalis ATCC 49452 and Bacillus cereus ATCC 10876, were used for the screening of the antibacterial activity.
The antibacterial activity was evaluated using the broth microdilution method to estimate the Minimal Inhibitory Concentration (MIC) according to the Clinical and Laboratory Standards Institute (CLSI) recommendations (CLSI, 2012). A series of two-fold dilutions from 1024 to $2 \mu \mathrm{g} \mathrm{ml}^{-1}$ were prepared in a 96 well sterile microplate. These dilutions were inoculated with 100 $\mu \mathrm{l}$ of a solution containing $10^{6}$ colony forming units (CFU).

Gentamicin and Ciprofloxacin were used as positive controls. The microplate was incubated at $37^{\circ} \mathrm{C}$ for $24 \mathrm{~h}$. The MIC was defined as the low concentration in which there was no turbidity.

\subsection{Scavenging activity}

In our study, the scavenging activity of the compounds was carried out by the technique of free radical 2,2-diphenyl1-picrylhydrazyl (DPPH) scavenging. The effect of each compound on DPPH was measured by the procedure described by Da Silva Pinto et al. ${ }^{26}$

A volume of $5 \mu \mathrm{l}$ of various concentrations of each compound was added to $1950 \mu \mathrm{l}$ of the methanol solution of DPPH. The negative control was prepared by mixing $50 \mu$ l of methanol with $1950 \mu$ l of the methanol solution of DPPH. The absorbance was measured at $517 \mathrm{~nm}$ against a blank of each concentration. These measurements were done after incubation in the dark for $30 \mathrm{~min}$, using a spectrophotometer. The positive control was a solution of the synthetic antioxidant butylated hydroxyanisole (BHA) with concentrations ranging from 0.02 to $0.2 \mathrm{mg} \mathrm{ml}^{-1}$. The absorbance was measured in the same conditions as the samples. The results were expressed taking into account the average of three measurements obtained for each sample, and the percentage of DPPH reduction was calculated using the formula:

$$
\operatorname{DPPH}(\%)=\frac{\left(\mathrm{A}_{\text {Control }}-\mathrm{A}_{\text {Sample }}\right)}{\mathrm{A}_{\text {Control }}} \times 100
$$

where DPPH (\%): Reduction percentage of DPPH.

$\mathrm{A}_{\text {Control }}$ : Absorbance of the negative control tube.

A $_{\text {Sample: }}$ Absorbance of the sample.

The $\mathrm{IC}_{50}$ value is the concentration that was reduced to $50 \%$ of the radical DPPH. It was determined graphically for each compound from the curve of the percentage reduction depending on the concentration.

\subsection{Ferric reducing antioxidant power assay (FRAP)}

The reducing power was determined by the measurement of absorbance at $700 \mathrm{~nm} .{ }^{27} \mathrm{~A}$ volume of $0.1 \mathrm{ml}$ of our compounds in different concentrations (initial) was mixed with $0.25 \mathrm{ml}$ of sodium phosphate buffer $(0.2 \mathrm{M}$; $\mathrm{pH}=6.6)$ and $0.25 \mathrm{ml}$ of potassium ferricyanide $1 \%(\mathrm{w} / \mathrm{v})$, and the mixture was incubated at $50^{\circ} \mathrm{C}$ for $20 \mathrm{~min}$. After $0.25 \mathrm{ml}$ of trichloroacetic acid (TCA), $10 \%(\mathrm{w} / \mathrm{v})$ were added, the mixture was centrifuged at $650 \mathrm{~g}$ for $10 \mathrm{~min}$ the supernatant $(0.5 \mathrm{ml})$ was mixed with $0.5 \mathrm{ml}$ distilled water and $0.1 \mathrm{ml}$ ferric chloride solution $\left(\mathrm{FeCl}_{3}\right)$ $0.1 \%(\mathrm{w} / \mathrm{v}) .{ }^{28} \mathrm{The} \mathrm{IC}_{50}$ value $(\mathrm{mg}$ compound/ $\mathrm{ml}$ ) is the effective concentration at which the absorbance was 0.5 for reducing power and was obtained by interpolation from linear regression analysis. For the same conditions, BHA and ascorbic acid were used as a positive control for comparison.

\subsection{Total antioxidant capacity (TAC)}

The total antioxidant capacity of our compounds was evaluated with the phosphor-molybdenum technique. ${ }^{29}$ An aliquot of $0.2 \mathrm{ml}$ of different concentrations of our compounds was combined with $2 \mathrm{ml}$ of reagent solution $(0.6 \mathrm{M}$ sulfuric acid, $28 \mathrm{mM}$ sodium phosphate and $4 \mathrm{mM}$ ammonium molybdate). The tubes were incubated in a thermal block at $95^{\circ} \mathrm{C}$ for $90 \mathrm{~min}$. The absorbance of each solution was measured at $695 \mathrm{~nm}$ 
against a blank. The antioxidant capacity was expressed in milligram equivalent of ascorbic acid per gram of compound $\left(\mathrm{mg}\right.$ EAA $\left.\mathrm{g}^{-1} \mathrm{C}\right)$. The range of the calibration curve of the ascorbic acid was 0.10 to $0.80 \mathrm{mg} \mathrm{ml}^{-1}$ (Table 3).

The MIC results of the synthesis products against references bacteria are shown in Table 4 .

The higher activity against gram-negative bacteria was obtained toward Pseudomonas aeruginosa. The product $4 \mathbf{e}$ showed a MIC equal to $16 \mu \mathrm{g} \mathrm{ml}^{-1}$. The products $3 \mathbf{e}, 3 \mathbf{b}$ and 3c showed MICs equal to $64 \mu \mathrm{g} \mathrm{ml}^{-1}$. Compound $\mathbf{3 d}$ showed a MIC equal to $256 \mu \mathrm{g} \mathrm{ml}^{-1}$. However, other gram-negative bacteria exhibited resistance to products tested. For grampositive bacteria, low MICs were obtained by the products $3 b$ and $3 \mathbf{c}$ and $4 \mathbf{e}$ against the Bacillus cereus strain; the MICs range was 32 to $128 \mu \mathrm{g} \mathrm{ml}^{-1}$. The compound 3e showed a MIC equal to $128 \mu \mathrm{g} \mathrm{ml}^{-1}$ against Bacillus cereus and Staphylococcus aureus.

The products $3 \mathbf{b}$ and $3 \mathrm{c}$ have $\mathrm{Cl}$ or $\mathrm{Br}$ halogen groups respectively at the 4-position, while the $3 \mathbf{e}$ has two $\mathrm{Cl}$ located in the 2- and 4-positions on the aromatic (phenyl) ring. The products with the electron-withdrawing groups in position 4 showed antibacterial activity with respect to gram-positive and -negative bacteria. These results are in accordance with the work of Nirav et al., ${ }^{30}$ which focused on the synthesis and evaluation of the antimicrobial activity of a new series of $4 \mathrm{H}$-chromenes against Staphylococcus aureus (S. aureus), and Bacillus subtilis (B. subtilis). The best result has been observed with chromene, which has a chlorine group. In the study of Sudhan and Mansoor, ${ }^{31}$ the synthesis and evaluation of the antimicrobial activity of a new series of 7,8-dihydro-2-(2-oxo-2H-chromen-3yl)-5-aryl-cyclopenta[b]pyranopyrimidine-4,6-5H-dione were investigated; the results suggest that aromatic substituents strongly influence antibacterial and antifungal activities.

In the chromeno[2,3-d] pyrimidines, the products $4 \mathbf{e}, 4 \mathbf{c}$, $4 \mathrm{~d}$ and $4 \mathrm{~b}$ showed interesting activities against Bacillus cereus (B. cereus) and Pseudomonas aeruginosa (P. aeruginosa). The best results were obtained with compound $4 \mathbf{e}$, where the structure of the chromeno pyrimidine is composed of two fused heterocyclic units, namely, the substituted $4 \mathrm{H}$-chromene and the pyrimidine. The pyrimidine has an amine in the 4-position of the ring. Chlorine is well known to have good bacterial activities, as shown in the case of $4 \mathbf{e}$.

These results agree with the work of Agrod, ${ }^{32}$ who found that the chlorine group linked to chromenopyrimidine heterocycles has good antibacterial activities compared to their analogues. The modification of the $4 \mathrm{H}$-chromene structure through the chromenopyrimidine products allowed the improvement of the antibacterial activity.

In the study of Sankappa et al., ${ }^{33}$ the new series of synthesised chromeno[2,3- $d$ ] pyrimidine compounds did not exhibit activity against: Staphylococcus aureus, Bacillus subtilis, Escherichia coli and
Table 3 Results of the antioxidant activity of the synthetic compound

\begin{tabular}{lccc}
\hline Compounds & $\begin{array}{c}\text { DPPH } \\
\text { IC50 mg C }\end{array}$ & $\begin{array}{c}\text { FRAP } \\
\text { EC50 mg ml }\end{array}$ & $\begin{array}{c}\text { TAC } \\
\text { m EAA g }^{-1} \mathrm{C}\end{array}$ \\
\hline BHA & $0.037 \pm 0$ & $\mathrm{ND}$ & $\mathrm{ND}$ \\
Ascorbic Acid & $0.047 \pm 0$ & $0.11 \pm 0.04$ & $1000 \pm 25,12$ \\
3e & $4.88 \pm 0.35$ & $5.28 \pm 0.50$ & $0.56 \pm 0.12$ \\
3d & $5.01 \pm 0.05$ & $5.32 \pm 1.74$ & $3.32 \pm 1.48$ \\
3b & $5.59 \pm 2.12$ & $4.43 \pm 0.45$ & $2.44 \pm 0.33$ \\
3c & $5.49 \pm 0.21$ & $4.51 \pm 0.66$ & $4.38 \pm 0.89$ \\
4e & $5.30 \pm 3.53$ & $7.75 \pm 1.45$ & $7.37 \pm 0.90$ \\
4c & $4.79 \pm 0.75$ & $5.01 \pm 0.52$ & $2.00 \pm 0.22$ \\
4d & $5.60 \pm 0.85$ & - & $1.77 \pm 0.18$ \\
4b & $5.60 \pm 2.03$ & $8.01 \pm 0.58$ & $5.02 \pm 0.56$ \\
\hline
\end{tabular}

ND. Not determined

Pseudomonas aeruginosa.

In the antioxidant study, two products (3e and $3 \mathbf{d}$ ) of the $4 \mathrm{H}$-chromenes family showed good DPPH scavenging activity. The products $3 \mathrm{~b}$ and $3 \mathrm{c}$ have $\mathrm{Cl}$ or $\mathrm{Br}$ respectively at the 4-position, while the $3 \mathbf{e}$ has two $\mathrm{Cl}$ located in the 2- and 4-positions of the aromatic (phenyl) ring. The grafting of electron-withdrawing halide substituents in position 4 improve the DPPH trapping activity. In iron reduction and antioxidant capacity, the situation is reversed; products $3 \mathbf{b}$ and $3 \mathbf{c}$ showed the most interesting reduction.

Concerning chromenopyrimidines, the $4 \mathrm{c}$ product showed the most interesting DPPH and iron reduction trapping activity. The grafting of electron-withdrawing halide substituents on the phenyl nucleus seems to improve this activity. The most important antioxidant capacity was obtained with $4 \mathbf{e}$. It seems that the grafting of the electron-donating groups improves this activity.

Finally, we can say that the importance of this research work lies in the possibility that an in-depth investigation of the structure-activity relationship, toxicity and biological effects of these compounds may be useful for designing more potent oxidising agents at higher concentrations for therapeutic purposes.

\section{Experimental}

The melting points were measured using a Bank Kofler HEIZBANK apparatus standard WME $50-260^{\circ} \mathrm{C}$ and were uncorrected. IR spectra were obtained with solids with a Fourier transform Perkin Elmer Spectrum One with ATR accessory. Only significant absorptions are listed in the results. The ${ }^{1} \mathrm{H}$ NMR spectra were recorded at $400 \mathrm{MHz}$ on a Brüker AC 400

Table 4. MIC values of the synthetic compounds

\begin{tabular}{|c|c|c|c|c|c|c|c|c|}
\hline Compounds & P. aeruginosa & E. coli & S. typhimurium & K. pneumoniae & C. freundii & S. aureus & E. flaecalis & B. cereus \\
\hline $3 e$ & $64 \pm 0$ & $>512$ & $>512$ & $>512$ & $>512$ & $128 \pm 0$ & $>512$ & $128 \pm 0$ \\
\hline $3 d$ & $256 \pm 0$ & $>512$ & $>512$ & $>512$ & $>512$ & $>512$ & $>512$ & $128 \pm 0$ \\
\hline $3 b$ & $64 \pm 0$ & $>512$ & $>512$ & $>512$ & $>512$ & $128 \pm 0$ & $>512$ & $32 \pm 0$ \\
\hline $3 c$ & $64 \pm 0$ & $>512$ & $>512$ & $>512$ & $>512$ & $128 \pm 0$ & $>512$ & $32 \pm 0$ \\
\hline $4 e$ & $16 \pm 0$ & $>512$ & $>512$ & $>512$ & $>512$ & $256 \pm 0$ & $>512$ & $32 \pm 0$ \\
\hline $4 d$ & $>512$ & $>512$ & $>512$ & $>512$ & $>512$ & $>512$ & $>512$ & $>512$ \\
\hline $4 b$ & $>512$ & $>512$ & $>512$ & $>512$ & $>512$ & $>512$ & $>512$ & $>512$ \\
\hline Gent & $0.5 \pm 0$ & $0.5 \pm 0$ & $0.25 \pm 0$ & $8 \pm 0$ & $0.5 \pm 0$ & $0.5 \pm 0$ & $16 \pm 0$ & $0.5 \pm 0$ \\
\hline Cip & $0.25 \pm 0$ & $0.008 \pm 0$ & $0.008 \pm 0$ & $0.25 \pm 0$ & $0.016 \pm 0$ & $0.25 \pm 0$ & $0.25 \pm 0$ & $0.064 \pm 0$ \\
\hline
\end{tabular}

MIC. Minimum Inhibitory Concentration $\left(\mu \mathrm{g} \mathrm{ml}^{-1}\right)$ 
spectrometer, and ${ }^{13} \mathrm{C}$ NMR spectra were recorded on the same spectrometers at $100.6 \mathrm{MHz}$. Samples were dissolved in DMSO- $\mathrm{d}_{6}$, values for $\delta$ are in parts per million relative to tetramethyl silane (TMS) as an internal standard. Mass spectra were recorded on a QTOF Micro (Waters). Microwave irradiation experiments use a microwave reactor (Biotage). The multiplicities are reported as $\mathrm{s}$ (singlet), d (doublet), t (triplet), q (quartet) and $\mathrm{m}$ (multiplet).

\subsection{Synthesis}

4.1.1. General procedure 1 for the synthesis of 2-amino-3-cyano$4 H$-chromenes $(3 a-h)$

A mixture of the aromatic aldehyde $(2 \mathbf{a}-\mathbf{e})(10 \mathrm{mmol})$, substituted resorcinol $(\mathbf{1} \mathbf{a}-\mathbf{b}) \quad(10 \mathrm{mmol})$, malononitrile (10 mmol), $\mathrm{H}_{2} \mathrm{O}(2 \mathrm{ml})$ and carbonate of ammonium $(0.5 \mathrm{~g})$ was irradiated in a single-mode microwave at $300 \mathrm{~W}$ for 5 min under 12 bar pressure. The completion of the reaction was determined by thin-layer chromatography (TLC). After the completion of the reaction, the residue that formed was diluted with $30 \mathrm{ml}$ of $\mathrm{CH}_{2} \mathrm{Cl}_{2}$. The organic layer obtained was washed with water $(3 \times 20 \mathrm{ml})$, then with a solution of saturated $\mathrm{NaCl}(10 \mathrm{ml})$, dried over $\mathrm{MgSO}_{4}$, filtered and evaporated under vacuum. The compounds 3a-h were obtained as white solids.

\subsubsection{General procedure 2 for the synthesis of-amino-5H-chrom-} eno[2,3-d] pyrimidines $(4 a-h)$

A mixture of $\mathbf{3 a}-\mathbf{h}(5 \mathrm{mmol})$ and formamidine acetate (15 mmol, 1,56 g) was irradiated in a single-mode microwave at $300 \mathrm{~W}$ for $15 \mathrm{~min}$ and under 12 bar pressure. TLC determined the completion of the reaction. After the completion of the reaction, the residue that formed was diluted with $30 \mathrm{ml}$ of $\mathrm{CH}_{2} \mathrm{Cl}_{2}$. The organic layer obtained was washed with water (3 $\times 20 \mathrm{ml}$ ), then with a solution of saturated $\mathrm{NaCl}(10 \mathrm{ml})$, dried over $\mathrm{MgSO}_{4}$, filtered and evaporated under vacuum to afford desired compounds $\mathbf{4 a - h}$.

2-amino-4-(bromophenyl)-3-cyano-7-hydroxy-4H-chromene (3c) was obtained, according to procedure 1 using 4-bromobenzaldéhyde (10 mmol; $1.83 \mathrm{~g})$, resorcinol (10 mmol; $1.10 \mathrm{~g})$ and malononitrile (10 mmol; $0.66 \mathrm{~g})$, as white solid; $89 \%^{\mathrm{a}}, 93 \%^{\mathrm{b}}$, or $97 \%^{\mathrm{c}}$; $\mathrm{mp} 251^{\circ} \mathrm{C}$.

${ }^{1} \mathrm{H}$ NMR (DMSO) $)_{\text {pppm }}: 9.80(1 \mathrm{H}, \mathrm{s}, \mathrm{OH}) ; 7.49\left(2 \mathrm{H}, \mathrm{d}, J_{H-H}=\right.$ $\left.8.40 \mathrm{~Hz}, \mathbf{H}_{\text {arom }}\right) ; 7.13\left(2 \mathrm{H}, \mathrm{d}, J_{\mathrm{H}-\mathrm{H}}=8.40 \mathrm{~Hz}, \mathbf{H}_{\text {arom }}\right) ; 6.91(2 \mathrm{H}, \mathrm{s}$, $\left.\mathrm{NH}_{2}\right) ; 6.78\left(1 \mathrm{H}, \mathrm{d}, J_{H-H}=8.40 \mathrm{~Hz}, \mathrm{H}_{\text {arom }}\right) ; 6.49\left(1 \mathrm{H}, \mathrm{dd}, J_{H-H}=\right.$ $\left.2.40 \mathrm{~Hz}, J_{H-H}=2.40 \mathrm{~Hz} \mathbf{H}_{\text {arom }}\right) ; 6.41\left(1 \mathrm{H}, \mathrm{d}, J_{H-H}=2 \mathrm{~Hz}, \mathbf{H}_{\text {arom }}\right)$; $4.64\left(1 \mathrm{H}, \mathrm{s}, \mathrm{H}_{\text {pyran }}\right)$.

${ }^{13}$ C NMR (DMSO) $)_{\text {ippm }}: 160.72(\mathrm{C}-\mathrm{OH}) ; 157.60\left(\mathrm{C}-\mathrm{O}-\mathrm{CNH}_{2}\right)$; $149.26\left(\mathrm{C}-\mathrm{NH}_{2}\right) ; 146.18-120.22\left(9 \times \mathrm{C}_{\text {arom }}\right) ; 113.57(\mathrm{CN}) ; 112.96$ $(\mathrm{C}=\mathrm{C}-\mathrm{O}) ; 102.72(\mathrm{C}=\mathrm{C}-\mathrm{CN}) ; 56.52(\mathbf{C H}-\mathrm{Ph})$.

IR (neat cm ${ }^{-1}$ ): 3457; 3340; 2220; 1645; 1597.

Results: $\mathrm{C}_{16} \mathrm{H}_{11} \mathrm{BrN}_{2} \mathrm{O}_{2} \mathrm{M}+\mathrm{H}$ 343.1703. Found 343.1704.

2-amino-3-cyano-7-hydroxy-4-p-tolyl-4H-chromène (3d) was obtained according to general procedure 1, using 4-methylbenzaldehyde (10 mmol; $1.20 \mathrm{~g})$, resorcinol (10 mmol $1.10 \mathrm{~g})$ and malononitrile $(10 \mathrm{mmol} ; 0.66 \mathrm{~g})$, as white solid; $85 \%^{\mathrm{a}}, 90 \%^{\mathrm{b}}$ or $96 \%$ c; $\mathrm{mp} 184^{\circ} \mathrm{C}$.

${ }^{1} \mathrm{H}$ NMR (DMSO) $)_{\text {oppm }}: 8.39(1 \mathrm{H}, \mathrm{s}, \mathrm{OH}) ; 7.11\left(2 \mathrm{H}, \mathrm{d}, J_{H-H}=\right.$ $\left.8.40 \mathrm{~Hz}, \mathbf{H}_{\text {arom }}\right) ; 7.07\left(2 \mathrm{H}, \mathrm{d}, J_{H-H}=8.40 \mathrm{~Hz}, \mathbf{H}_{\text {arom }}\right) ; 6.81(2 \mathrm{H}$, $\left.\mathrm{s}, \mathrm{NH}_{2}\right) ; 6.78\left(1 \mathrm{H}, \mathrm{d}, J_{H-H}=8.40 \mathrm{~Hz}, \mathbf{H}_{\text {arom }}\right) ; 6.52\left(1 \mathrm{H}, \mathrm{d}, J_{H-H}=\right.$ $\left.8.40 \mathrm{~Hz}, \mathbf{H}_{\text {arom }}\right) ; 6.47\left(1 \mathrm{H}, \mathrm{dd}, J_{H-H}=2.40 \mathrm{~Hz}, J_{\mathrm{H}-\mathrm{H}}=2.40 \mathrm{~Hz}\right.$ $\left.\mathbf{H}_{\text {arom }}\right) ; 4.49\left(1 \mathrm{H}, \mathrm{s}, \mathbf{H}_{\text {pyran }}\right) ; 2.26\left(3 \mathrm{H}, \mathrm{s}, \mathrm{CH}_{3}\right)$.

${ }^{13} \mathrm{C}$ NMR (DMSO) $)_{\text {oppm: }} 160.20(\mathrm{C}-\mathrm{OH}) ; 157.53\left(\mathrm{C}-\mathrm{O}-\mathrm{CNH}_{2}\right)$; $149.88\left(\mathbf{C}-\mathrm{NH}_{2}\right) ; 143.36-120.96\left(9 \times \mathrm{C}_{\text {arom }}\right) ; 113.87(\mathrm{CN}) ; 112.81$ $(\mathrm{C}=\mathrm{C}-\mathrm{O}) ; 103.00(\mathrm{C}=\mathrm{C}-\mathrm{CN}) ; 56.94(\mathrm{CH}-\mathrm{Ph}) ; 21.06\left(\mathrm{CH}_{3}\right)$.

IR (neat cm ${ }^{-1}$ ): 3420; 3416; 2217; 1649; 1622.

Results: $\mathrm{C}_{17} \mathrm{H}_{14} \mathrm{~N}_{2} \mathrm{O}_{2} \mathrm{M}+\mathrm{H} 278.3099$. Found 278.3101.

2-amino-4-(2,4-dichlorophenyl)-3-cyano-6-hydroxy-4Hchromene (3e) was obtained, according to general procedure 1 using 2,4-dichlorobenzaldehyde (10 mmol; $1.75 \mathrm{~g})$, resorcinol
(10 mmol; $1.10 \mathrm{~g})$ and malononitrile (10 mmol; $0.66 \mathrm{~g})$, as white solid; $88 \%^{\mathrm{A}}, 90 \%^{\mathrm{B}}, 95 \% \mathrm{C}$; $\mathrm{mp} 256^{\circ} \mathrm{C}$.

${ }^{1} \mathrm{H}$ NMR (DMSO) $)_{\delta \mathrm{ppm}}: 9.80(1 \mathrm{H}, \mathrm{s}, \mathrm{OH}) ; 7.58\left(1 \mathrm{H}, \mathrm{d}, J_{H-H}=\right.$ $\left.2.10 \mathrm{~Hz}, \mathrm{H}_{\text {arom }}\right) ; 7.40\left(1 \mathrm{H}, \mathrm{dd}, J_{H-H}=2.10 \mathrm{~Hz}, J_{H-H}=2 \mathrm{~Hz}\right.$, $\left.\mathbf{H}_{\text {arom }}\right) ; 7.21\left(1 \mathrm{H}, \mathrm{d}, J_{H-H}=12 \mathrm{~Hz}, \mathbf{H}_{\text {arom }}\right) ; 6.98\left(2 \mathrm{H}, \mathrm{s}, \mathrm{NH}_{2}\right) ; 6.72$ $\left(1 \mathrm{H}, \mathrm{d}, J_{H-H}=8.40 \mathrm{~Hz}, \mathbf{H}_{\text {arom }}\right) ; 6.49\left(1 \mathrm{H}, \mathrm{dd}, J_{H-H}=2.40 \mathrm{~Hz}, J_{H-H}\right.$ $\left.=2.40 \mathrm{~Hz} \mathbf{H}_{\text {arom }}\right) ; 6.42\left(1 \mathrm{H}, \mathrm{d}, J_{H-H}=2.00 \mathrm{~Hz}, \mathbf{H}_{\text {arom }}\right) ; 5.13(1 \mathrm{H}$, $\left.\mathrm{s}, \mathrm{H}_{\text {pyran }}\right)$.

${ }^{13}$ C NMR (DMSO) $)_{\text {dppm }}: 160.95(\mathbf{C}-\mathrm{OH}) ; 157.95\left(\mathbf{C}-\mathrm{O}-\mathrm{CNH}_{2}\right) ; 149.49$ $\left(\mathbf{C}-\mathrm{NH}_{2}\right) ; 142.37-120.63\left(9 \times \mathbf{C}_{\text {arom }}\right) ; 113.5(\mathbf{C N}) ; 112.33(\mathbf{C}=\mathrm{C}-\mathrm{O})$; $102.74(\mathrm{C}=\mathbf{C}-\mathrm{CN}) ; 54.87(\mathbf{C H}-\mathrm{Ph})$.

IR (neat cm ${ }^{-1}$ ): 3417; 3342; 2198; 1647; 1595.

Results: $\mathrm{C}_{16} \mathrm{H}_{10} \mathrm{Cl}_{2} \mathrm{~N}_{2} \mathrm{O}_{2} \mathrm{M}+\mathrm{H}$ 333.1760. Found 333.1762 .

4-amino-5-(4-bromophenyl)-8-hydroxy-5H-chromeno[2,3-d] pyrimidine (4c) was obtained, according to general procedure 2 using 3c (5 mmol, $1.71 \mathrm{~g})$, as white solid; $91 \%$; $\mathrm{mp} 240^{\circ} \mathrm{C}$.

${ }^{1} \mathrm{H}$ NMR (DMSO) $)_{\text {oppm }}: 9.98(1 \mathrm{H}, \mathrm{s}, \mathrm{OH}) ; 9.80\left(1 \mathrm{H}, \mathrm{s}, \mathbf{H}_{\text {pyrimidine }}\right)$; $7.49\left(2 \mathrm{H}, \mathrm{d}, J_{H-H}=8.40 \mathrm{~Hz}, \mathrm{H}_{\text {arom }}\right) ; 7.13\left(2 \mathrm{H}, \mathrm{d}, J_{\mathrm{H}-\mathrm{H}}=8.40 \mathrm{~Hz}\right.$, $\left.\mathbf{H}_{\text {arom }}\right) ; 6.91\left(2 \mathrm{H}, \mathrm{s}, \mathrm{NH}_{2}\right) ; 6.78\left(1 \mathrm{H}, \mathrm{d}, J_{H-H}=8.40 \mathrm{~Hz}, \mathbf{H}_{\text {arom }}\right)$; $6.54\left(1 \mathrm{H}, \mathrm{dd}, J_{H-H}=2.40 \mathrm{~Hz}, J_{H-H}=2.40 \mathrm{~Hz} \mathbf{H}_{\text {arom }}\right) ; 6.42(1 \mathrm{H}, \mathrm{d}$, $\left.J_{H-H}=2.40 \mathrm{~Hz}, \mathbf{H}_{\text {arom }}\right) ; 4.64\left(1 \mathrm{H}, \mathrm{s}, \mathbf{H}_{\text {pyrane }}\right)$.

${ }^{13}$ C NMR (DMSO) $)_{\text {oppm: }}$ : $162.84(\mathrm{C}-\mathrm{O}) ; 160.72\left(\mathrm{C}-\mathrm{NH}_{2}\right) ; 157.66$ (C$\mathrm{OH}) ; 149,26(-\mathrm{N}-\mathrm{C}=\mathrm{N}-) ; 146,18(\mathrm{C}=\mathrm{C}-\mathrm{N}) ; 132.77-120.22(9 \times$

$\left.\mathrm{C}_{\text {arom }}\right) ; 113.57(\mathrm{C}=\mathrm{C}-\mathrm{Ph}) ; 112.96(\mathrm{C}=\mathrm{C}-\mathrm{N}) ; 102.72(\mathrm{CH}-\mathrm{Ph})$.

IR (neat cm ${ }^{-1}$ ): 3439; 3440; 1669; 1569.

Results: $\mathrm{C}_{17} \mathrm{H}_{12} \mathrm{BrN}_{3} \mathrm{O}_{2} \mathrm{M}+\mathrm{H}$ 370.0191. Found 370.0203.

4-amino-8-hydroxy-5-p-tolyl-5H-chromeno[2,3- $d]$ pyrimidine

(4d) was obtained, according to general procedure 2 using $3 \mathrm{~d}$ (5 mmol, 1.39), as white solid; $91 \%$; $\mathrm{mp} 210^{\circ} \mathrm{C}$.

${ }^{1} \mathrm{H}$ NMR (DMSO) $)_{\text {oppm }}: 9.68$ ( $\left.1 \mathrm{H}, \mathrm{s}, \mathrm{OH}\right) ; 8.08$ ( $\left.1 \mathrm{H}, \mathrm{s}, \mathbf{H}_{\text {pyrimidine }}\right)$; $7.14\left(2 \mathrm{H}, \mathrm{d}, J_{H-H}=8.00 \mathrm{~Hz}, \mathbf{H}_{\text {arom }}\right) ; 7.04\left(2 \mathrm{H}, \mathrm{d}, J_{\mathrm{H}-\mathrm{H}}=8.00 \mathrm{~Hz}\right.$, $\left.\mathbf{H}_{\text {arom }}\right) ; 6.95\left(1 \mathrm{H}, \mathrm{d}, J_{\mathrm{H}-\mathrm{H}}=8.40 \mathrm{~Hz}, \mathbf{H}_{\text {arom }}\right) ; 6,72\left(2 \mathrm{H}, \mathrm{s}, \mathrm{NH}_{2}\right)$; $6.53\left(1 \mathrm{H}, \mathrm{dd}, J_{H-H}=2.40 \mathrm{~Hz}, J_{H-H}=2.40 \mathrm{~Hz} \mathbf{H}_{\text {arom }}\right) ; 6.50(1 \mathrm{H}$, $\left.\mathrm{d}, J_{H-H}=2.40 \mathrm{~Hz}, \mathbf{H}_{\text {arom }}\right) ; 5.09\left(1 \mathrm{H}, \mathrm{s}, \mathbf{H}_{\text {pyran }}\right) ; 3.19\left(3 \mathrm{H}, \mathrm{s}, \mathrm{CH}_{3}\right)$. ${ }^{13} \mathrm{C}$ NMR (DMSO) ${ }_{\text {dppm }}$ : $163.08(\mathrm{C}-\mathrm{O}) ; 162.81\left(\mathrm{C}-\mathrm{NH}_{2}\right) ; 157.57$ $(\mathrm{C}-\mathrm{OH}) ; 156.86(-\mathrm{N}-\mathrm{C}=\mathrm{N}-) ; 150.40(\mathrm{C}=\mathrm{C}-\mathrm{N}) ; 142.54-113.13(9$ $\left.\times \mathrm{C}_{\text {arom }}\right) ; 112.73(\mathrm{C}=\mathrm{C}-\mathrm{O}) ; 103.40(\mathrm{C}=\mathrm{C}-\mathrm{N}) ; 96.66(\mathrm{CH}-\mathrm{Ph})$; $20.99\left(\mathrm{CH}_{3}\right)$.

IR (neat cm ${ }^{-1}$ ): 3444; 3413; 1647; 1595.

Results: $\mathrm{C}_{18} \mathrm{H}_{15} \mathrm{~N}_{3} \mathrm{O}_{2} \mathrm{M}+\mathrm{H}$ 305. 3334. Found 305.333

4 - a m in o - 5 - ( 2, 4 - di ch 1 or op hén y 1$)$ - 8 - h y d roxy - 5 H chromeno $[2,3-d]$ pyrimidine (4e) was obtained, according to general procedure 2 using $3 \mathbf{e}(5 \mathrm{mmol}, 1.66 \mathrm{~g})$, as white solid; $95 \%$; $\mathrm{mp} 250^{\circ} \mathrm{C}$.

${ }^{1} \mathrm{H}$ NMR (DMSO) $)_{\text {oppm }}: 9.78$ ( $\left.1 \mathrm{H}, \mathrm{s}, \mathrm{OH}\right) ; 8.12\left(1 \mathrm{H}, \mathrm{s}, \mathbf{H}_{\text {pyrimidine }}\right)$; $7,52\left(2 \mathrm{H}, \mathrm{d}, J_{H-H}=8 \mathrm{~Hz}, \mathbf{H}_{\text {arom }}\right) ; 7.39\left(1 \mathrm{H}, \mathrm{d}, J_{H-H}=8 \mathrm{~Hz}, \mathbf{H}_{\text {arom }}\right)$; $6.89\left(1 \mathrm{H}, \mathrm{d}, J_{H-H}=8 \mathrm{~Hz}, \mathrm{H}_{\text {arom }}\right) ; 6.53\left(1 \mathrm{H}, \mathrm{dd}, J_{H-H}=2.40 \mathrm{~Hz}\right.$, $\left.J_{H-H}=2.40 \mathrm{~Hz} \mathbf{H}_{\text {arom }}\right) ; 6.48\left(1 \mathrm{H}, \mathrm{d}, J_{H-H}=2.40 \mathrm{~Hz}, \mathbf{H}_{\text {arom }}\right) ; 6.33$ $\left(2 \mathrm{H}, \mathrm{s}, \mathrm{NH}_{2}\right) ; 5.51\left(1 \mathrm{H}, \mathrm{s}, \mathbf{H}_{\text {pyran }}\right)$.

${ }^{13}$ C NMR (DMSO) $)_{\delta p p m}: 163.11(C-O) ; 163.02\left(C-\mathrm{NH}_{2}\right) ; 158.08(\mathrm{C}-$ $\mathrm{OH}) ; 157.30(-\mathrm{N}-\mathrm{C}=\mathrm{N}-) ; 150.50(\mathrm{C}=\mathrm{C}-\mathrm{N}) ; 140.41-112.84(9 \times$

$\left.\mathrm{C}_{\text {arom }}\right) ; 112.84(\mathrm{C}=\mathrm{C}-\mathrm{O}) ; 103.27(\mathrm{C}=\mathrm{C}-\mathrm{N}) ; 94.60(\mathrm{CH}-\mathrm{Ph})$.

IR (neat cm ${ }^{-1}$ ): 3379; 3427; 1647; 1585.

Results: $\mathrm{C}_{17} \mathrm{H}_{11} \mathrm{Cl}_{2} \mathrm{~N}_{3} \mathrm{O}_{2} \mathrm{M}+\mathrm{H} 360.0307$ Found 360.0309

\section{Conclusions}

In conclusion, we have successfully developed a novel and efficient approach for synthesising new chromenes and $5 H$-chromeno[2,3- $d]$ pyrimidines derivatives under solventfree conditions and microwave irradiations with high yields. The originality of our synthetic strategy is based on the use of formamidine acetate as cyclisation agents. This easy to execute methodology with rapid access and good yields open a new route for synthesising various substituted nitrogen heterocycles of biological and pharmaceutical. Evaluating the antioxidant and antibacterial activity of the various compounds tested against three bacterial strains showed good activity. 


\section{Acknowledgements}

The authors wish to thank Karine Jarsalé for the mass spectroscopy spectra. We gratefully acknowledge financial support from the 'Ministère de la Recherche et des Nouvelles Technologies', CNRS (Centre National de la Recherche Scientifique), the 'Region Basse-Normandie' and the European Union (FEDER funding). The authors acknowledge the financial support of the French Agence Nationale de la Recherche (ANR) through the program 'Investissements d'Avenir' (ANR10-LABX-09-01) LabEx EMC. We thank DGRSDST and the University of Tlemcen- Algeria for funding this work.

\section{ORCID iDs}

Fatima Belhadj: https://orcid.org/0000-0001-6238-0430

\section{References}

1 L. Moafi, S. Ahadi, A. Bazgir. New HA 14-1 analogues: synthesis of 2-amino-4-cyano-4H-chromenes. Tetrahedron Lett. 2010, 51, 6270-6274.

2 A.H. Abd El-Wahab. Synthesis, reactions and evaluation of the antimicrobial activity of some 4-(p-Halophenyl)-4H-naphthopyran, pyranopyrimidine and pyranotriazolopyrimidine derivatives. Pharmaceuticals (Basel), 2012, 5, 745-757.

3 N. Karimi, A. Davoodnia, M. Pordel. Synthesis of new $3 \mathrm{H}$-chromeno[2,3- $d$ ] pyrimidine- $4,6(5 \mathrm{H}, 7 \mathrm{H})$ diones via the tandem intramolecular Pinner/Dimroth rearrangement. Heterocycl. Commun., 2018, 24, 31-35.

4 R.A. Haggam, G. Mohamed, M.G. Assy, K.M. Enaiat, S.M. Abdussattar. Synthesis of pyrano[2,3-d]pyrimidine-2,4-diones and pyridino[2,3-d]pyrimidine-2,4,6,8-tetraones: Evaluation antitumor activity. J. Heterocycl. Chem., 2019, 57, 842-850.

5 R. Ghahremanzadeh, F. Fereshtehnejad, A. Bazgir. Chromeno[2,3-d] pyrimidine-triones synthesis by a three-component coupling reaction. Chem. Pharm. Bull. (Tokyo), 2010, 58, 516-520.

6 F. Eiden, F. Denk. Synthesis of CNS-activity of pyran derivatives: 6, 8-dioxabicyclo (3, 2, 1) octane]. Arch. Pharm. (Weinheim), 1999, 324, 353-354.

7 A. El-Wahab. AHF Synthesis of some new pyrano [2, 3-d][1, 2, 4] triazolo $[1,5-c]$ pyrimidine and pyrimido $[1,6-b]$ triazine derivatives. Acta Pharm., 2003, 58, 701-720.

8 K.M. Meepagala, K.K. Schrader, C.L. Burandt, D.E. Wedge, S.O. Duke. New class of algicidal compounds and fungicidal activities derived from a chromene amide of Amyris texana. J. Agric. Food Chem., 2010, 58, 9476-9482.

9 Kitamura N, Onishi A. In: European Patent 163599, 1984, Chem. Abstr., 1984, p 186439.

10 G.H. Churchill, S.A. Raw, L. Powell. Improved synthesis of substituted pyrido[2,3-d]pyrimidinediones. Tetrahedron Lett., 2011, 52, 3657-3661.

11 C.W. Johannes, M.S. Visser, G.S. Weatherhead, A.H. Hoveyda. Zrcatalyzed kinetic resolution of allylic ethers and Mo-catalysed chromene formation in synthesis. Enantioselective total synthesis of the antihypertensive agent (S, R, R, R)-Nebivolol. J. Am. Chem. Soc., 1998, 120, 8340-8347.

12 F. Belhadj, Z. Kibou, N. Cheikh, N. Choukchou-Braham, D. Villemin. Convenient access to new 4-substituted aminopyrido [2, 3- $d]$ pyrimidine derivatives. Tetrahedron Lett., 2015, 56, 5999-6002.

13 M. Benabdallah, O. Talhi, F. Nouali, N. Choukchou-Braham, Kh. Bachari, A.M.S. Silva. Advances in spirocyclic hybrids: chemistry and Medicinal actions. Curr. Med. Chem., 2018, 25, 3748-3767.

14 Z. Kibou, D. Villemin, J.-F. Lohier, N. Cheikh, N. Bar, N. ChoukchouBraham. Easy solventless synthesis of new mono and bis amino-5Hchromeno [3, 4-c] pyridin-5-one derivatives. Tetrahedron, 2016, 72, 1653-1661.

15 D. Villemin, Z. Belhadj, N. Cheikh, N. Choukchou-Braham, N. Bar, J-F. Lohier. Solventless convenient synthesis of new cyano-2- aminopyridine derivatives from enaminonitriles. Tetrahedron Lett., 2013, 54, 1664-1668.

16 S-P. Eszter, S-F. Rita. Application of ionic liquids in synthetic procedures leading to pharmaceutically active organic compounds. Curr. Green Chem., 2018, 5, 4-21.

17 N. Martin, C. Pascual, C. Seoane, J. Soto. The use of some activated nitriles in heterocyclic syntheses. Heterocycles, 1987, 26, 2811-2816.

18 S. RaoKolla, Y.R. Lee. $\mathrm{Ca}(\mathrm{OH})_{2}$-mediated efficient synthesis of 2-amino-5-hydroxy- $4 \mathrm{H}$-chromene derivatives with various substituents. Tetrahedron, 2011, 67, 8271-8275.

19 S. Khaksar, A. Rouhollahpour, S.M. Talesh. A facile and efficient synthesis of 2-amino-3-cyano- $4 H$-chromenes and tetrahydrobenzo $[b]$ pyrans using 2,2,2-trifluoroethanol as a metal-free and reusable medium. J. Fluor. Chem., 2012, 141, 11-15.

20 J. Safari, Z. Zarnegar, M. Heydarian. Practical, ecofriendly, and highly efficient synthesis of 2-amino- $4 H$-chromenes using nanocrystalline $\mathrm{MgO}$ as a reusable heterogeneous catalyst in aqueous media. J. Taibah Univ. Sci., 2013, 7, 17-25.

21 J. Albadi, A. Razeghi, A. Mansournezhad, Z. Azarian. CuO-CeO nanocomposite catalysed efficient synthesis of aminochromenes. J. Nanostructure Chem., 2013, 3, 85.

22 K.R. Desale, K.P. Nandre, S.L. Patil. p-Dimethylaminopyridine (DMAP): A highly efficient catalyst for one pot, solvent free synthesis of substituted 2-amino-2-chromenes under microwave irradiation. Org. Comm., 2012, 5.

23 J. Malviya, P. Rana Krishna. One-pot three-component synthesis of chromeno [2,3-d] pyrimidine derivatives: Novel, simple, and efficient electrochemical approach. J. Heterocycl. Chem., 2019, 57, 39-49.

24 A. Mobinikhaledi, N. Foroughifar, T. Mosleh, A. Hamta. Synthesis of some novel chromenopyrimidine derivatives and evaluation of their biological activities. Iranian J. Pharm. Res., 2014, 13, 873.

25 Z. Ebrahimi, A. Davoodnia, A. Motavalizadehkakhky, J. Mehrzad. Synthesis of benzo[f]chromeno[2,3- $d$ ]pyrimidines via the tandem intramolecular Pinner/Dimroth rearrangement and their antibacterial and antioxidant evaluation. Org. Prep. Proced. Int., 2019, 51, 357-367.

26 A.K. Gupta, K. Kumari, N. Singh, D.S. Raghuvanshi, K.N. Singh. An eco-safe approach to benzopyranopyrimidines and $4 \mathrm{H}$-chromenes in ionic liquid at room temperature. Tetrahedron Lett., 2012, 53, 650-653.

27 M. Da Silva Pinto, F.M. Lajolo, M.I. Genovese. Bioactive compounds and quantification of total ellagic acid in strawberries (Fragaria $\times$ ananassa Duch.). Food Chem., 2008, 107, 1629-1635.

$28 \mathrm{M}$. Oyaizu. Antioxidative activities of products of browning reaction prepared from glucosamine. Jap. J. Nutr. Diet., 1986, 44, 307-315.

29 A.A. Karagozler, B.B. Erdag, Y. Emek, D.A. Uygun. Antioxidant activity and proline content of leaf extracts from Dorystoechas hastata. Food Chem., 2008, 111, 400-407.

30 S. Barek, N.M. Rahmoun, M. Aissaoui, I.A. El Haci, C. Bensouici, N. Choukchou-Braham. Phenolic contents, antioxidant, and antibacterial activities of the Algerian Genista saharae solvent extracts. J. Herbs Spices Med. Plants, 2019, 26, 1-13.

31 N.K. Shah, N.M. Shah, M.P. Patel, R.G. Patel. Synthesis of 2-amino$4 \mathrm{H}$-chromene derivatives under microwave irradiation and their antimicrobial activity. J. Chem. Sci., 2013, 125, 525-530.

32 P.N. Sudhan, S.S. Mansoor. Facile synthesis and antimicrobial activity of a novel series of 7,8-dihydro-2-(2-oxo-2H-chromen-3-yl)5-aryl-cyclopenta[b]pyrano-pyrimidine-4,6-5H-dione derivatives catalysed by reusable silica-bonded N-propyl diethylenetriamine sulfamic acid. J. Assoc. Arab. Univ. Basic. App. Sc., 2016, 21, 1-9.

33 A.M. El-Agrody, N.M. Sabry, S.S. Motlaq. Synthesis and antimicrobial activities of 2 -substituted $12 \mathrm{H}$-chromeno[3,2-e][1,2,4] triazolo[1,5-c] pyrimidines, 3-ethoxycarbonyl-12H-chromeno[3,2-e][1,2,4] triazolo [1,5-c] pyrimidine-2-one and ethyl 2-formylamino- and 2-acetylamino- $4 \mathrm{H}$ chromene-3-carboxylates. J. Chem. Res., 2011, 35, 77-83. 